\title{
Benthic community structure and ecosystem functions in above- and below-waterfall pools in Borneo
}

\author{
Kate Baker (1) - Michael A. Chadwick • \\ Rodzay A. Wahab $\cdot$ Rafhiah Kahar
}

Received: 8 June 2016/Revised: 22 August 2016/ Accepted: 29 August 2016/Published online: 23 September 2016

(C) The Author(s) 2016. This article is published with open access at Springerlink.com

\begin{abstract}
Waterfalls are geomorphic features that often partition streams into discrete zones. Our study examined aquatic communities, litter decomposition and periphyton growth rates for above- and belowwaterfall pools in Ulu Temburong National Park, Brunei. We observed higher fish densities in below-

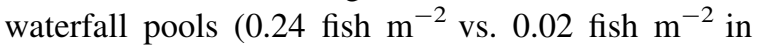
above-waterfall pools) and higher shrimp abundance in above-waterfall pools (eight shrimp/pool vs. less than one shrimp/pool in below-waterfall pools). However, macroinvertebrate densities (excluding shrimp) were similar among both pool types. Ambient periphyton was higher in below-waterfall pools in 2013 (4.3 vs. $2.8 \mathrm{~g} \mathrm{~m}^{-2}$ in above-waterfall pools) and 2014 (4.8 vs. $3.4 \mathrm{~g} \mathrm{~m}^{-2}$ in above-waterfall pools), while periphyton growth rates varied from 0.05 to $0.26 \mathrm{~g} \mathrm{~m}^{-2}$ days $^{-1}$ and were significantly higher in
\end{abstract}

Handling editor: Checo Colón-Gaud

Electronic supplementary material The online version of this article (doi:10.1007/s10750-016-2975-4) contains supplementary material, which is available to authorized users.

K. Baker $(\bowtie) \cdot$ M. A. Chadwick

Department of Geography, King's College London, London, UK

e-mail: kate.baker@kcl.ac.uk

\section{R. A. Wahab · R. Kahar}

Institute for Biodiversity and Environmental Research, Universiti Brunei Darussalam, Bandar Seri Begawan,

Brunei Darussalam below-waterfall pools in 2014. Leaf litter decomposition rates $\left(0.001\right.$ to 0.024 days $\left.^{-1}\right)$ did not differ between pool types, suggesting that neither shrimp nor fish densities had consistent impacts on this ecosystem function. Regardless, this research demonstrates the varied effects of biotic and abiotic factors on community structure and ecosystem function. Our results have highlighted the importance of discontinuities, such as waterfalls, in tropical streams.

Keywords Waterfalls - Ecosystem functions ·

Tropical streams · Borneo - Macroinvertebrates · Fish · Biotopes

\section{Introduction}

Tropical streams often support large populations of macroconsumers, such as herbivorous fish, crabs, tadpoles and shrimp (Power, 1984; Flecker, 1992; Rosemond et al., 1998), which can have a significant impact on stream ecosystems via predation and/or competition for food resources like leaf litter and periphyton among a range of other resident animals (Pringle \& Hamazaki, 1997; Rosemond et al., 1998). Leaf litter is often abundant and important as a functional habitat (sensu Harper et al., 1995) in tropical headwater streams and is broken down by aquatic animals (i.e. shredders; Wootton \& Oemke, 1992; Crowl et al., 2001; March et al., 2001; Yule 
et al., 2009; Coughlan et al., 2010). Periphyton covers many benthic surfaces in tropical streams and is the main food source for herbivorous animals, which can limit both periphyton standing stocks and growth rates (Power, 1984; Flecker, 1992; Feminella \& Hawkins, 1995; Steinman, 1996; Pringle \& Hamazaki, 1997; Flecker \& Taylor, 2004; Moulton et al., 2015).

While availability of food resources is important for regulating both community structure and ecosystem functions, physical factors are also important (Bond \& Downes, 2000). Waterfalls are fast flowing, rocky biotopes with distinct geomorphic structure (e.g. channel slopes and stream channels typically erode down to parent material). These biotopes flow vertically without obstruction and are generally more than $1 \mathrm{~m}$ in height (Newson \& Newson, 2000). In spite of their potential importance in tropical streams, waterfalls have not received as much attention as other biotopes (Rackemann et al., 2013; Clayton \& Pearson, 2016). In high elevation localities, waterfalls become common because the stream gradient steepens and the river channels form discrete, sequential pools and waterfalls (or cascades and riffles). The discontinuities in channel form caused by waterfalls are barriers to the upstream dispersal of fish and thus create discrete communities (Creed, 2006; Covich et al., 2009; Hein \& Crowl, 2010; Karssing et al., 2012; El-Sabaawi et al., 2015). In tropical streams, below-waterfall pools support a range of predacious and herbivorous fish (Choy, 1996); in contrast, above-waterfall pools tend to have few fish and often become a refuge for shrimp (Covich et al., 2009; Hein \& Crowl, 2010). However, Bass (2007) notes that different aquatic communities in above- and below-waterfall pools may be the result of differences in microhabitats or other environmental conditions.

The different community structures of fish and shrimp above and below waterfalls can influence a range of ecosystem functions including organic matter decomposition and periphyton growth (Greathouse \& Pringle, 2006; Moulton et al., 2010; Ho \& Dudgeon, 2016). Below waterfalls, high numbers of fish can play an important role in controlling periphyton growth by clearing rock surfaces after frequent tropical flood events (Pringle \& Hamazaki, 1998). Above waterfalls, where shrimp can be abundant, organic matter breakdown rates may be increased by consumption and shredding of leaf litter by resident shrimp (Crowl et al., 2001; March et al., 2001; Coughlan et al., 2010). Fish and shrimp can also reduce macroinvertebrate densities, as many are insectivorous (Pringle \& Hamazaki, 1998). Macroinvertebrates, a term which refers to invertebrates excluding shrimp in this study, are also important in restricting periphyton growth (Feminella \& Hawkins, 1995; Steinman, 1996; Moulton et al., 2015) and breaking down organic matter (Cheshire et al., 2005; Masese et al., 2014). Therefore, fish and shrimp may have an indirect impact on ecosystem functions by reducing macroinvertebrate densities. The separation of communities and its impact on ecosystem structure and function have been researched to some extent, with mixed results, in the Neotropics (Pringle \& Hamazaki, 1998; March et al., 2002; Ramirez \& Hernandez-Cruz, 2004; Covich et al., 2009). However, there have been few similar studies conducted in tropical Asia despite the similarity of the region's biotic and abiotic conditions to those of the Neotropics (Mantel et al., 2004; Ho \& Dudgeon, 2016).

The natural fragmentation of tropical streams by waterfalls provides a "natural experiment" for examining these biotic and physical factors. This study investigated four streams in Ulu Temburong National Park, Brunei Darussalam, all with waterfalls that reduce the upstream dispersal of fish, creating a refuge for shrimp in above-waterfall pools. The aim of this study was to investigate the extent to which waterfalls influence fish community structure and how expected declines in fish densities in above-waterfall pools affect the density and biomass of both shrimp and nonshrimp macroinvertebrates. In addition, we tested the hypothesis that ecosystem functions (i.e. periphyton growth and leaf litter breakdown rates) differed between above- and below-waterfall pools. We hypothesized that both shrimp and macroinvertebrates occur in higher densities in the above-waterfall pools lacking fish and that periphyton growth rates are higher in above-waterfalls pools owing to the lower number of herbivorous fish. Leaf litter breakdown rates were also hypothesized to be higher in abovewaterfall pools owing to the higher numbers of shrimp and macroinvertebrates.

\section{Materials and methods}

Study sites

Small tributaries of Sungai Belalong and Sungai Temburong in the Temburong district, Brunei Darussalam (in 
northern Borneo), were the focus of this study (Fig. 1). The four streams (Sungai Lower Apan, Sungai Baki, Sungai Esu and Sungai Apan Threelan; Fig. 1) were in the vicinity of the Kuala Belalong Field Studies Centre (KBFSC). They were chosen because they have perennial flows and catchments covered in primary rainforest (Cranbrook \& Edwards, 1994). The climate in Brunei Darussalam is tropical and weakly influenced by the Southeast Asia monsoon (Dykes, 1996). The daily weather pattern in the rainforest of Ulu Temburong is very erratic, with most rain originating from convection cells formed over the ocean. As the cells move inland, they are forced to rise over the mountains of Bukit Belalong and Bukit Pagon, thereby condensing and producing daily heavy rain (Cranbrook \& Edwards, 1994). Topography ranges from $30 \mathrm{~m}$ asl at the Kuala Belalong Field Study Centre but rises to $913 \mathrm{~m}$ asl at Bukit Belalong and to 1,850 $\mathrm{m}$ asl at Bukit Pagon (Dykes, 1994). The streams drain V-shaped valleys with steep bank slopes.

Water quality can have a strong impact on benthic communities and ecosystem functions (Giller \& Malmqvist, 1998; Everaert et al., 2014). This study was therefore conducted in streams that are not under any anthropogenic impacts in the catchment (Cranbrook \&
Edwards, 1994). Further, the similar geology and catchment conditions suggest water quality should be relatively uniform among all the study streams. In a pilot study, nitrate and phosphate were found to occur at concentrations less than 0.55 and $0.08 \mathrm{mg} \mathrm{l}^{-1}$, respectively. Any variation in ecosystem structure and function in the streams of Ulu Temburong National Park are thus assumed to be attributable to biotic interactions among resident taxa (e.g. competition for resources and predation) and to natural abiotic conditions, including physical disturbances cause by variable river discharges.

Physical disturbances are assumed to be similar across all pool biotopes owing to the consistent gradient of the streams. Light levels were also assumed to be similar across our study pools, with gaps in canopies (of approximately 70-90\%) created by the waterfalls extending to both the above- and below-waterfall pools. Lower Apan was the longest reach $(90 \mathrm{~m})$ of the four reaches, followed by Apan Threelan $(75 \mathrm{~m})$, Esu $(70 \mathrm{~m})$ and Baki $(55 \mathrm{~m})$. The waterfalls at Threelan and Baki were furthest from their respective confluences with Temburong compared to the other study streams (separated by over $300 \mathrm{~m}$ ). This may affect the numbers of fish present in

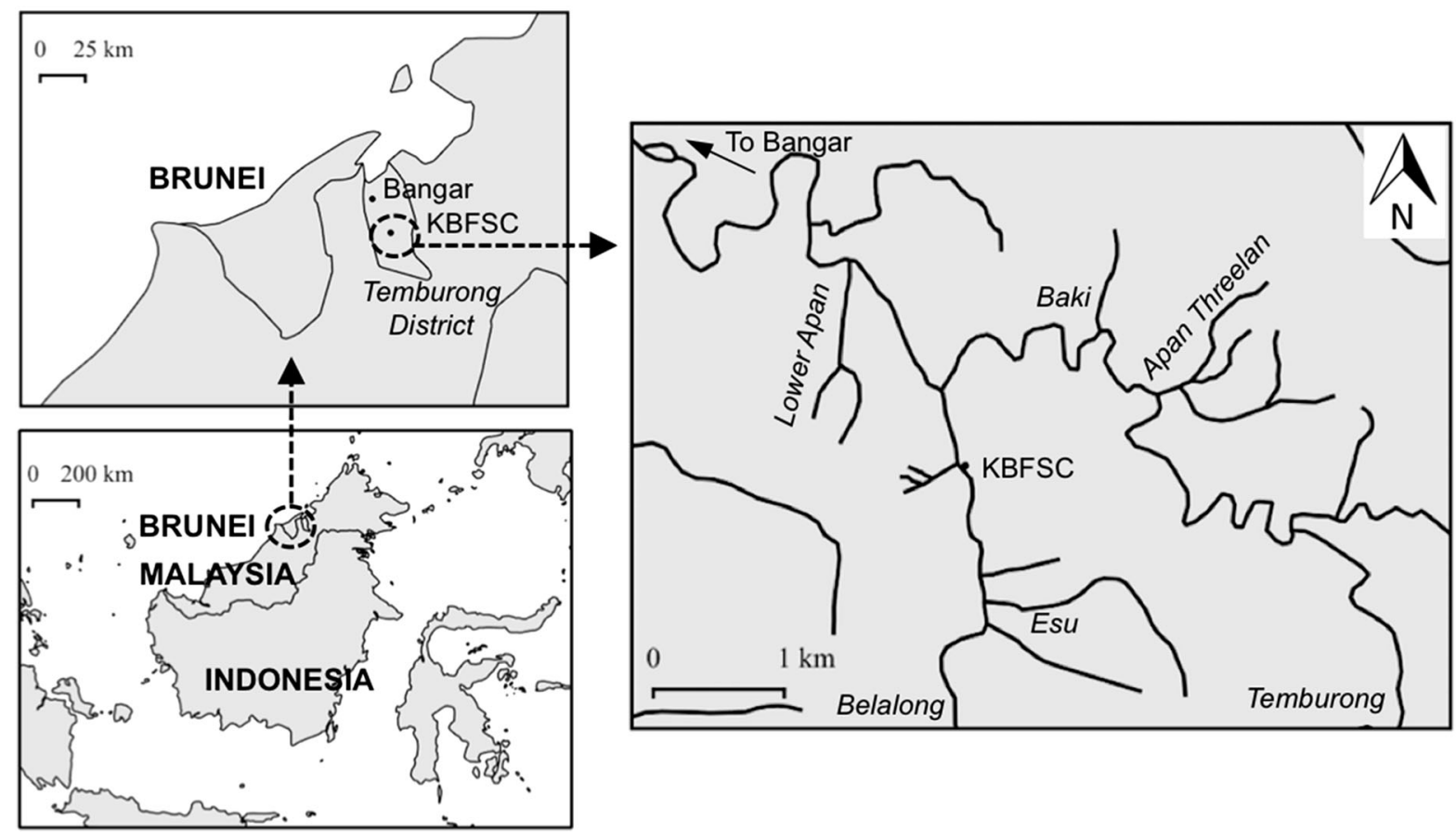

Fig. 1 Map showing the location of Brunei Darussalam in northern Borneo and the Temburong District. The four study streams were Sungai Lower Apan, Sungai Baki, Sungai
Threelan and Sungai Esu, which are highlighted along with the main rivers Sungai Belalong and Sungai Temburong as well as Kuala Belalong Field Study Centre (KBFSC) 
the tributaries, with fish dispersing into the tributaries as refuges during high discharges. The waterfall at Esu was approximately $150 \mathrm{~m}$ from its confluence with Belalong, and Lower Apan was approximately $60 \mathrm{~m}$ from its confluence with Temburong (Online Appendix 1).

\section{Background community structure}

A total of 44 species of fish from 10 families and 30 genera have been identified in the streams and rivers of Ulu Temburong National Park (Choy \& Chin, 1994). Species of Cyprinoidea were predominant, with families Balitoridae (river loaches) and Cyprinidae being the most commonly represented (Choy \& Chin, 1994). In general, cyprinids have a mixed diet that changes with their life stage and includes insects, algae, diatoms and higher plants (McConnell \& LoweMcConnell, 1987), while the endemic genus Gastromyzon (Balitoridae) comprises herbivorous fish that feed on periphyton exclusively (Tan, 2006).

Three genera of freshwater shrimp live in the streams of Ulu Temburong National Park with the most common being Macrobrachium (Decapoda: Palaemonidae; Wowor, personal communication). Macrobrachium are omnivorous, but predominantly predaceous (Crowl \& Covich, 1994). The other shrimp in Ulu Temburong, which were not present in this study, include Caridina (Decapoda: Atyidae), which are found in headwater streams, and Atyopsis (Decapoda: Atyidae), which are present in streams with strong currents (Wowor, personal communication). A previous study of non-shrimp macroinvertebrates in these streams (Baker et al., in press) identified 14 orders, with Diptera being the most abundant in number of individuals (approximately 40\%), followed by Coleoptera (approximately 20\%), Ephemeroptera (approximately 20\%) and Trichoptera (9\%).

\section{Physical habitat measurements}

Wetted and bankfull widths and channel depths were measured in three pools above the waterfall and three pools below the waterfall, except at Esu and Lower Apan, where there were only two pools below the waterfall. At these locations, the benthic substrate was assessed visually and characterized by percentage cover of gravel, cobble, boulder and bedrock. A formal cross-section of velocity and depth was taken at the widest point of each pool every $0.5 \mathrm{~m}$ following common methods described by Gordon et al. (2004). Stream velocity was measured using an electromagnetic flowmeter (Valeport ${ }^{\circledR}$ model 801; Valeport, Totnes, UK). A two-way analysis of variance (ANOVA) was used to assess differences in the width, wetted width, depth and velocity of the study pools among streams and between the pools above and below the waterfalls. This analysis was carried out in the statistical computing environment $\mathrm{R}$ ( $\mathrm{R}$ Core Team 2013).

\section{Macroinvertebrates, shrimp and fish sampling}

Macroinvertebrates and shrimp were sampled in three pools above each waterfall and in all the pools below the waterfall to the confluence. Surber samples $\left(0.1 \mathrm{~m}^{2} ; 250-\mu \mathrm{m}\right.$ mesh $)$ were used to collect macroinvertebrates, excluding shrimp. Three Surber samples were randomly selected in each pool where it was shallow enough to sample and composited together to create one sample. A combination of three Surber samples and a single 3-min kick sample with a standard D-frame net (500- $\mu \mathrm{m}$ mesh) was used to sample freshwater shrimp in each pool. Shrimp and macroinvertebrates were considered separately, as shrimp are significantly larger than the other macroinvertebrates and are more vagile. Samples were preserved in $70 \%$ ethanol in the field and processed under $(\times 10)$ magnification in the laboratory. Individuals were identified to the lowest practical taxonomic level (most often to genus or morphotype to an assumed similar level) and measured to the nearest $0.5 \mathrm{~mm}$. Macroinvertebrate taxonomic knowledge in northern Borneo is poor; therefore, identifications were conducted using the few keys available (e.g. Dudgeon, 1999; Yule \& Yong, 2004; Sangpradub \& Boonsoong, 2007), alongside open source identification methods. Specifically, taxa were photographed and uploaded onto the Flickr website (http://flickr.com/photos/tropical-streams/ sets/), where interested experts commented or requested to see the actual specimens. Ash-free dry mass (AFDM) of macroinvertebrates was estimated using length-mass regressions (Benke et al., 1999; Sabo et al., 2002; McNeely et al., 2007). In cases in which no taxon-specific equations were available, estimates were made using equations from taxa with similar body 
shapes (Ramírez \& Pringle, 1998). Where only dry mass (DM) estimates were available, values were converted to AFDM following the calculation described by Waters (1977). All macroinvertebrates were considered to be capable of feeding on periphyton and organic matter except known predators, i.e. Odonata, Hemiptera and Hydracarina (Jinggut, 2015). Unfortunately macroinvertebrate and shrimp specimens from Baki were severely damaged in transit, so the analysis for macroinvertebrates and shrimp includes only those from Lower Apan, Esu and Threelan.

In contrast to the macroinvertebrate sampling procedures, fish were only sampled in pools directly above and below the first waterfall upstream from each confluence. Fish were sampled with a cast net (mesh size, $0.64 \mathrm{~cm}^{2}$ ) thrown into each of the sample pools three times. Fish were photographed and identified following the methods described by Choy \& Chin (1994). Fish were categorized as herbivorous or predacious using appropriate scholarly literature, and percentages of fish belonging to these categories were calculated (McConnell \& Lowe-McConnell, 1987; Tan, 2006; Kottelat, 2013). Once processed, fish were immediately returned to streams.

ANOVAs were used to assess differences in biodiversity of macroinvertebrates and shrimp among study sites and between pools above and below the waterfalls, followed by Tukey's tests to identify significant factors. As fish were only sampled in pools directly above and below the waterfall, it was not possible to assess differences among study sites. For the analysis, each pool was considered as a replicate, rather than the samples within each pool. To satisfy the assumptions of normality and homoscedasticity, fish and shrimp data were transformed [using a $\log _{10}(n+1)$ transformation]. Macroinvertebrate assemblage structure in above- and below-waterfall pools were examined via a non-metric multidimensional scaling (NMDS) analysis using abundance data followed by an analysis of similarities (ANOSIM; Clarke, 1993) to test for differences in abundance and composition of macroinvertebrates among the above- and below-waterfall pools. Surber samples were combined to give a single estimate per pool. The statistical computing environment R (R Core Team 2013) and the R packages mass and vegan were used to conduct the ANOVA, NMDS and ANOSIM procedures. The Bray-Curtis dissimilarity index, a dissimilarity index for ecological data, was used for the NMDS procedure (Borcard et al., 2012).

Ecosystem function estimates

Leaf litter decomposition rates and periphyton growth estimates were conducted in pools directly above and below the waterfall at each study stream.

\section{Leaf litter decomposition estimates}

Leaves from the genus Campnosperma (Family: Anacardiaceae) were used to estimate decomposition rates in pools above and below waterfalls. Although there are approximately 250 species of trees in Ulu Temburong National Park (Cranbrook \& Edwards, 1994), Campnosperma was most abundant along the study streams and therefore chosen for this experiment. Leaves from one large branch that had recently fallen into one of the study streams were used in this experiment. Decomposition rates were estimated using standard litter bag techniques (Irons et al., 1994; Benstead, 1996). Prior to the experiment, leaves were dried at $70^{\circ} \mathrm{C}$ for $24 \mathrm{~h}$, cooled and then weighed. Three grams of leaves were placed into nylon litter bags (mesh size, approximately $8 \mathrm{~mm}$ ). Leaf litterbags were placed at Lower Apan, Esu, Apan Threelan and Baki. Litter bags were collected from the study sites after 7, 23, 26 or 71 days in the field and processed immediately in the KBFSC laboratory. The leaves were picked out by hand and the remaining material was processed through a $250-\mu \mathrm{m}$ sieve, with macroinvertebrates picked out and preserved in $70 \%$ ethanol. Macroinvertebrates were then identified and measured using the methods described above. Leaf material remaining was dried at $70^{\circ} \mathrm{C}$ for $24 \mathrm{~h}$, cooled and weighed. Breakdown rates $\left(k_{\mathrm{d}}\right)$ were calculated using the equation:

$k_{\mathrm{d}}=\frac{\ln (\text { final mass } / \text { initial mass })}{\text { days }}$.

Litter bag experiments were conducted in both 2013 and 2014. In the first year, three replicates per study pool were left in study pools for 7- and 23-day exposures. In the second year, the same methods were repeated except four replicates were used, and leaf litter bags were deployed for longer periods of time, 26 and 71 days, in order to take account of the scouring effects of high discharge. 


\section{Periphyton growth}

Periphyton growth rates were determined as the standing stocks through time and estimated from rocks located in the same pools used for the leaf decomposition experiment. Random rocks from each stream were selected, placed in boiling water for 10 min and scrubbed with a wire brush to remove all periphyton. Rocks were then placed into the study pools with plastic wire used to secure them to the riverbed. After exposure, periphyton abundance was estimated from rock scrubs. A fixed area $\left(0.002 \mathrm{~m}^{2}\right)$ of each rock was sampled with material removed and collected onto GFF filters. Filters were dried at KBFSC and transported back to the UK for AFDM analysis. AFDM was calculated by taking the difference between the dry biofilm weight and ash weight (obtained from heating samples to $500^{\circ} \mathrm{C}$ for $1 \mathrm{~h}$ ). AFDM was then used as an estimate of periphyton abundance. Periphyton growth rates were calculated as the difference between final and initial standing stocks (AFDM) divided by the total exposure time (days). It should be noted that our estimates of periphyton cannot distinguish between living and dead algal cells (Wellnitz \& Poff, 2006). This method was selected because of the remote location and limited facilities at KBFSC. Periphyton experiments were conducted in both 2013 and 2014. In the first year, four rocks per study pool were left for 23-day exposures. In the second year, the same methods were repeated, but with five replicate rocks, and each was deployed for 71-day exposures. In each year, ambient levels of periphyton were estimated from four random rocks in each study pool in order to ensure that the periphyton levels from the experiment were consistent with the background standing stock.

The statistical computing environment $\mathrm{R}$ ( $\mathrm{R}$ Core Team 2013) was used to conduct a one-way ANOVA to evaluate differences in leaf litter breakdown rates and periphyton growth rates between the above- and below-waterfall pools. Assumptions of normality and homoscedasticity were tested with graphical methods, and in order to satisfy the statistical assumptions, many of the datasets collected were transformed (Thomas et al., 2013). A $\log _{10}(n+1)$ transformation was applied to the 7-day exposure leaf litter bag macroinvertebrate data and the 23-day exposure leaf litter bag macroinvertebrate biomass and abundance data from 2013. A square root transformation was applied to the 2013 and 2014 ambient periphyton rock scrub data as well as the 2014 litter bag data on macroinvertebrates, including the 28-day exposure macroinvertebrate biomass and richness data, the 71-day exposure macroinvertebrate biomass data, the 28-day exposure non-predacious macroinvertebrate abundance data and the 71-day exposure macroinvertebrate biomass data.

\section{Results}

Physical habitat

There were no significant statistical differences in pool widths, depths or velocities either among streams or between above- and below-waterfall pools (Online Appendix 1). The substrates of above-waterfall pools were $36 \%$ bedrock compared to $7 \%$ bedrock in belowwaterfall pools. In contrast, there was a higher substrate percentage of cobbles in below-waterfall pools $(31 \%)$ compared to above-waterfall pools $(17 \%)$.

Macroinvertebrates, shrimp and fish

Total macroinvertebrate richness in the pools differed among the streams with 37 taxa at Lower Apan, 50 at Esu and 61 at Threelan (two-way ANOVA, $F_{2,12}=$ 4.62, $P=0.04$; Online Appendices 2-4). Average density was lower at Lower Apan $(205 \pm 29$ individuals $\left.\mathrm{m}^{-2}\right)$ than at Threelan (300 \pm 54 individuals $\left.\mathrm{m}^{-2}\right)$ and Esu (531 \pm 98 individuals $\mathrm{m}^{-2} ; F_{2,12}=6.52, P=$ 0.01). Biomass was also lower at Lower Apan (58 \pm $7 \mathrm{mg} \mathrm{m}^{-2}$ ) than at Threelan $\left(187 \pm 47 \mathrm{mg} \mathrm{m}^{-2}\right)$ and Esu $\left(213 \pm 54 \mathrm{mg} \mathrm{m}^{-2} ; F_{2,12}=9.25, P=0.005\right)$. There were no differences between above- and belowwaterfall pools in total macroinvertebrate richness $\left(F_{1,12}=0.47, P=0.51\right)$, density $\left(F_{1,12}=0.02, P=\right.$ $0.89)$ or biomass $\left(F_{1,12}=0.16, P=0.70\right)$. Additionally, the NMDS showed no clear pattern or difference in macroinvertebrate community structure between aboveand below-waterfall pools (stress value, $>0.2$; Online Appendix 5), and the ANOSIM procedure revealed no difference between the macroinvertebrate community structure of the above- and below-waterfall pools (global $R=0.35 ; P=0.24$ ).

Only one shrimp taxon (Macrobrachium) was present in the three study streams Lower Apan, Esu and Threelan 
Fig. 2 Bar plots showing the average density of fish, shrimp and

macroinvertebrates.

Macroinvertebrate density was estimated using Surber samples and shrimp data from Surber and kick samples for each pool both above and below the waterfalls. Error bars represent standard errors (all below-waterfall pools, $n=8$; all above-waterfall pools, $n=9$; Sungai Apan Threelan, $n=6$; Sungai Esu, $n=5$; Sungai Lower Apan $n=6$ ). No error bars are presented for fish density because all samples were combined in the field. There was a significant difference between above- and belowwaterfall densities of fish $(P=0.04)$ and shrimp $(P \leq 0.01)$, but no difference in macroinvertebrate densities $(P=0.89)$. There was also a significant difference in macroinvertebrate densities among the study streams ( $P=0.01)$
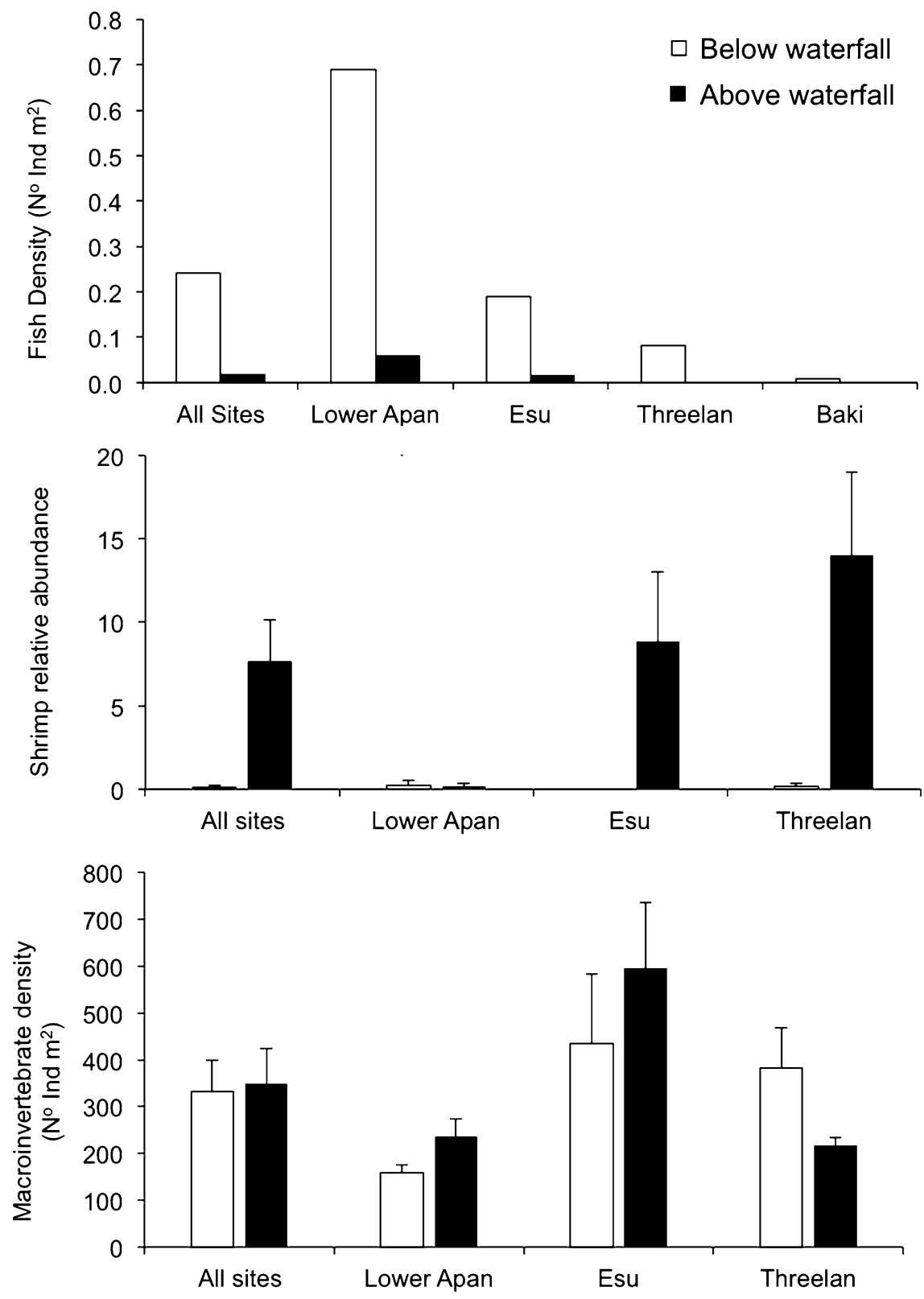

(Fig. 2 and Online Appendix 6). Shrimp abundance differed among the study streams from $0.2 \pm 0.13$ individuals at Lower Apan to $7.1 \pm 3.17$ individuals at Threelan $\left(F_{2,12}=4.3, P=0.04\right)$. Shrimp biomass varied from $20.7 \pm 19.80 \mathrm{mg}$ at Lower Apan to $2,217 \pm 1,182.74 \mathrm{mg}$ at Threelan $\left(F_{2,12}=5.6, P=\right.$ 0.02). Shrimp abundance was highest in above-waterfall pools (7.67 \pm 2.47 individuals vs. $0.14 \pm 0.10$ individuals; $F_{1,12}=18.75, P=0.001$; Fig. 2). Shrimp biomass was also highest in above-waterfall pools $\left(2,701.02 \pm 618.31 \mathrm{mg}\right.$ vs. $19.61 \pm 20.93 \mathrm{mg} ; F_{1,12}=$ 24.55, $P=0.0005)$.

It was not possible to identify all fish to the species level, particularly the smallest individuals. However, six distinct taxa were sampled across the four streams with a total of 75 individuals collected during the survey (Online Appendix 6). The most abundant fish were cyprinids, comprising $97 \%$ of observed fish, with the most abundant species being Nematabramis steindachneri Popta, 1905 (32 fish) and Rasbora 
Table 1 Average leaf litter breakdown rates $\left(k_{\mathrm{d}}\right)$ for pools above and below waterfalls in 2013 (over 7 and 23 days) along with macroinvertebrate (both all and non-predacious) mean richness, abundance and biomass (AFDM)

\begin{tabular}{|c|c|c|c|c|c|c|}
\hline Stream & $\begin{array}{l}\text { Exposure } \\
\text { (days) }\end{array}$ & $\begin{array}{l}\text { Above versus } \\
\text { below waterfall }\end{array}$ & $\begin{array}{l}\text { Breakdown } \\
\text { rates }\left(k_{\mathrm{d}}\right)\end{array}$ & $\begin{array}{l}\text { Richness (taxa/bag) } \\
\text { All | non-pred. }\end{array}$ & $\begin{array}{l}\text { Abundance (individuals/ } \\
\text { bag) All I non-pred. }\end{array}$ & $\begin{array}{l}\text { Biomass }(\mathrm{mg} / \mathrm{bag}) \\
\text { All | non-pred. }\end{array}$ \\
\hline \multirow{4}{*}{$\begin{array}{l}\text { Lower } \\
\text { Apan }\end{array}$} & \multirow[t]{2}{*}{7} & Above & -0.013 & $1.3 \mid 1.0$ & $2.0 \mid 1.7$ & $0.35 \mid 0.04$ \\
\hline & & Below & -0.010 & $1.7 \mid 1.7$ & $1.7 \mid 1.7$ & $0.45 \mid 0.45$ \\
\hline & \multirow[t]{2}{*}{23} & Above & -0.008 & $1.0 \mid 1.0$ & $2.3 \mid 2.3$ & $0.15 \mid 0.15$ \\
\hline & & Below & -0.008 & $0 \mid 0$ & $0 \mid 0$ & $0 \mid 0$ \\
\hline \multirow[t]{4}{*}{ Baki } & \multirow[t]{2}{*}{7} & Above & -0.011 & $1 \mid 0.67$ & $1.3 \mid 1.0$ & $7.09 \mid 1.73$ \\
\hline & & Below & -0.019 & $3 \mid 2.33$ & $4.3 \mid 3.7$ & $0.27 \mid 0.15$ \\
\hline & \multirow[t]{2}{*}{23} & Above & -0.009 & $1.0 \mid 1.0$ & $2.0 \mid 2.0$ & $0.11 \mid 0.11$ \\
\hline & & Below & -0.016 & $2.0 \mid 1.7$ & $2.0|0| 1.7$ & $0.42 \mid 0.37$ \\
\hline \multirow[t]{4}{*}{ Esu } & \multirow[t]{2}{*}{7} & Above & -0.022 & $0.3 \mid 0.3$ & $0.3 \mid 0.3$ & $0.19 \mid 0.19$ \\
\hline & & Below & -0.009 & $3.0 \mid 3.0$ & $5.3 \mid 5.3$ & 1.09 | 1.09 \\
\hline & \multirow[t]{2}{*}{23} & Above & -0.008 & $2.3 \mid 2.3$ & $4 \mid 4$ & $1.56 \mid 1.56$ \\
\hline & & Below & -0.011 & $3.7 \mid 3.3$ & $4.7 \mid 4.3$ & $0.96 \mid 0.94$ \\
\hline \multirow[t]{4}{*}{ Threelan } & \multirow[t]{2}{*}{7} & Above & -0.013 & $1.5 \mid 1.0$ & $2.0 \mid 1.5$ & $0.23 \mid 0.19$ \\
\hline & & Below & -0.012 & $1.7 \mid 1.3$ & $3.7 \mid 3.3$ & $1.50 \mid 0.04$ \\
\hline & \multirow[t]{2}{*}{23} & Above & -0.005 & $3.7 \mid 3.7$ & $10.3 \mid 10.3$ & $0.26 \mid 0.26$ \\
\hline & & Below & -0.002 & $5.0 \mid 4.7$ & $5.0 \mid 4.7$ & $0.88 \mid 0.81$ \\
\hline
\end{tabular}

Leaf litter breakdown rates significantly differed among streams in 2013 over 23 -day exposures $(P \leq 0.01)$. Higher leaf litter decay rates were also found in 2013 over 23 -day exposures below the waterfalls $(P \leq 0.01)$. There was no significant difference in macroinvertebrate biodiversity or shredder diversity between pools above and below the waterfalls

argyrotaenia (Bleeker, 1850) (24 fish). The other 3\% of fish were Gastromyzon. Average fish densities were significantly lower in above-waterfall pools $\left(0.02 \pm 0.02 \mathrm{fish} / \mathrm{m}^{2}\right.$ vs. $0.24 \pm 0.27 \mathrm{fish} / \mathrm{m}^{2} ; F_{1,6}=$ $6.00, P=0.04)$. There were no fish in above-waterfalls pools at Baki and Threelan, but fish were present in above-waterfalls pools at Esu (Gastromyzon) and at Lower Apan (Cyprinidae).

Ecosystem function estimates

\section{Leaf litter decomposition}

In 2013, there was no difference in average leaf litter breakdown rates between above- and below-waterfall pools over 7 days (0.017 vs. 0.012 days $^{-1}$, respectively; $\left.F_{1,21}=2.6, P=0.1\right)$, but there was a difference over 23 days $\left(0.008\right.$ vs. 0.010 days $^{-1}$, respectively; $F_{1,22}=9, P=0.008$ ) with faster decay rates occurring in below-waterfall pools (Table 1). Comparisons between macroinvertebrates in leaf litter bags in above- and below-waterfall pools revealed no statistical differences in richness, density or biomass (Table 1). No relationships were observed between leaf litter breakdown rate and macroinvertebrate richness $\left(R^{2}=0.02\right)$, abundance $\left(R^{2}=0.02\right)$ or biomass $\left(R^{2}<0.01\right)$. Overall in both experiments leaf litter bag recovery was $>95 \%$.

In 2014, there were significantly higher leaf litter breakdown rates in above-waterfall pools over 26 days (0.005 vs. 0.004 days $^{-1} ; F_{1,29}=24.80$, $P \leq 0.001)$, but no difference over 71 days $(0.008$ vs. 0.005 days $^{-1} ; F_{1,28}=3.40, P=0.07$; Fig. 3 ). Over the 71-day exposure, there was a higher abundance of macroinvertebrates accumulated in the leaf litter bags of below-waterfall pools $\left(F_{1,28}=12.78\right.$, $P=0.002)$. However, there were no significant correlations found between leaf litter breakdown rate and macroinvertebrate richness $\left(R^{2}=0.17\right)$, abundance $\left(R^{2}=0.13\right)$ or biomass $\left(R^{2}<0.01\right)$. In both 2013 and 2014, some of the leaf litter bags were scoured out during storm events. Overall in both experiments, leaf litter bag recovery was $>83 \%$. 
Table 2 Average leaf litter breakdown rates $\left(k_{\mathrm{d}}\right)$ for pools above and below waterfalls in 2014 (over 26 and 71 days) along with macroinvertebrate (both all and non-predacious) mean richness, abundance and biomass (AFDM)

\begin{tabular}{|c|c|c|c|c|c|c|}
\hline Stream & $\begin{array}{l}\text { Exposure } \\
\text { (days) }\end{array}$ & $\begin{array}{l}\text { Above versus } \\
\text { below waterfall }\end{array}$ & $\begin{array}{l}\text { Breakdown } \\
\text { rates }\left(k_{\mathrm{d}}\right)\end{array}$ & $\begin{array}{l}\text { Richness (taxa/bag) } \\
\text { All | non-pred. }\end{array}$ & $\begin{array}{l}\text { Abundance (individuals/ } \\
\text { bag) All | non-pred. }\end{array}$ & $\begin{array}{l}\text { Biomass }(\mathrm{mg} / \mathrm{bag}) \\
\text { All } \mid \text { non-pred. }\end{array}$ \\
\hline \multirow{4}{*}{$\begin{array}{l}\text { Lower } \\
\text { Apan }\end{array}$} & \multirow[t]{2}{*}{26} & Above & -0.004 & $2.5 \mid 1.5$ & $2.5 \mid 1.5$ & $0.32 \mid 0.29$ \\
\hline & & Below & -0.006 & $1 \mid 0$ & $3.3 \mid 0$ & $0.76 \mid 0$ \\
\hline & \multirow[t]{2}{*}{71} & Above & -0.011 & $5.5 \mid 4.3$ & $11.5 \mid 7.5$ & $0.65 \mid 0.37$ \\
\hline & & Below & -0.001 & $3.3 \mid 2.3$ & $5.5 \mid 2$ & $1.10 \mid 0.13$ \\
\hline \multirow[t]{4}{*}{ Baki } & \multirow[t]{2}{*}{26} & Above & -0.016 & $3.8 \mid 2.5$ & $9.7 \mid 5.8$ & $2.16 \mid 2.08$ \\
\hline & & Below & -0.004 & $5.8 \mid 4.5$ & $16 \mid 6.8$ & $1.72 \mid 1.02$ \\
\hline & \multirow[t]{2}{*}{71} & Above & -0.002 & $3.5 \mid 2$ & $11 \mid 2$ & $0.85 \mid 0.40$ \\
\hline & & Below & -0.001 & $3.8 \mid 2.8$ & $13.8 \mid 5.8$ & $1.34 \mid 1.06$ \\
\hline \multirow[t]{4}{*}{ Esu } & \multirow[t]{2}{*}{26} & Above & -0.024 & $9.3 \mid 7.5$ & $26 \mid 13$ & 4.03 | 2.99 \\
\hline & & Below & -0.005 & $0 \mid 0$ & $0 \mid 0$ & $0 \mid 0$ \\
\hline & \multirow[t]{2}{*}{71} & Above & -0.002 & $3.5 \mid 2$ & $5.3 \mid 2.8$ & $3.8 \mid 3.2$ \\
\hline & & Below & -0.006 & 615 & $29 \mid 10.2$ & $3.59 \mid 2.59$ \\
\hline \multirow[t]{4}{*}{ Threelan } & \multirow[t]{2}{*}{26} & Above & -0.005 & $1.5 \mid 0.75$ & $4.5 \mid 1$ & $0.97 \mid 0.88$ \\
\hline & & Below & -0.004 & $6 \mid 4.5$ & $13.3 \mid 7.5$ & $20.67 \mid 17.72$ \\
\hline & \multirow[t]{2}{*}{71} & Above & -0.005 & $2 \mid 1$ & $7 \mid 1$ & $1.84 \mid 1.84$ \\
\hline & & Below & -0.005 & $4 \mid 2.8$ & $17.3 \mid 6.8$ & $0.83 \mid 0.31$ \\
\hline
\end{tabular}

There was a significant difference in leaf litter breakdown rates between pools above and below waterfalls over 71-day exposures $(P \leq 0.01)$. Over 71-day exposures, a higher abundance of macroinvertebrates accumulated in below-waterfall pools $(P=0.002)$. A higher abundance of non-predacious macroinvertebrates also occurred in pools below waterfalls $(P=0.01)$, whilst non-predacious invertebrate biomass was higher in above-waterfall pools $(P=0.001)$

\section{Periphyton growth rates}

In 2013, ambient periphyton biomass averaged $2.8 \pm$ $0.35 \mathrm{~g} \mathrm{~m}^{-2}$ in above-waterfalls pools and $4.3 \pm 0.19$ $\mathrm{g} \mathrm{m}^{-2}$ in below-waterfall pools. In 2014, ambient periphyton averaged $3.4 \pm 0.57 \mathrm{~g} \mathrm{~m}^{-2}$ in above-waterfall pools and $4.8 \pm 0.37 \mathrm{~g} \mathrm{~m}^{-2}$ in below-waterfall pools. There were statistically higher levels of ambient periphyton in below-waterfall pools in both 2013 (oneway ANOVA, $F_{1,29}=21.90, P \leq 0.01$ ) and in 2014 $\left(F_{1,20}=4.50, P=0.05\right)$. In 2013 , there was no difference in periphyton growth rates above- and belowwaterfall pools $\left(F_{1,15}=1.23, P=0.30\right.$; Table 3$)$, but in 2014, periphyton growth rates were higher in belowwaterfall pools (two-way ANOVA, $F_{1,33}=25.70$, $P \leq 0.01)$. In 2013 , we had $70 \%$ recovery and in $201487 \%$ recovery.

\section{Discussion}

Waterfalls can affect the distribution of aquatic animals by partitioning streams into discrete zones
(Covich et al., 2009; Hein \& Crowl, 2010). Tropical headwater streams in Ulu Temburong National Park contain a large number of shrimp and fish, with waterfalls acting as semi-permeable filters that create different aquatic communities in reaches above and below waterfalls. We found below-waterfall pools supported a higher density of fish and significantly higher ambient periphyton levels in 2013 and 2014 (Table 4). Higher growth rates of periphyton were also found in below-waterfall pools in 2014. Above-waterfalls pools supported a higher abundance and biomass of shrimp, but there was no difference in macroinvertebrate biodiversity between above- and below-waterfall pools and no consistent statistical difference in leaf litter decomposition rates in 2013 or 2014. These findings illustrate how geomorphology can isolate biotopes, creating discontinuities in streams that affect community structure, specifically with respect to fish and shrimp. However, the corresponding impact on ecosystem functions is less straightforward, suggesting differing degrees of influence of biotic and abiotic factors on ecosystem functions. 
Fig. 3 Leaf litter decomposition in pools above and below waterfalls (top) over 23 days in 2013 and (bottom) over 72 days in 2014. Differences were significant in leaf litter breakdown rates $\left(k_{\mathrm{d}}\right)$ among streams in 2013 over 23-day exposures $(P \leq 0.01)$ and in 2014 over 26 -day exposures $(P \leq 0.01)$ and 71 -day exposures $(P \leq 0.01)$. In 2013, faster decay rates occurred over 23-day exposures below the waterfalls $(P \leq 0.01)$, whilst in 2014, over 26-day exposures, decay rates were higher in pools above the waterfall $(P \leq 0.01)$

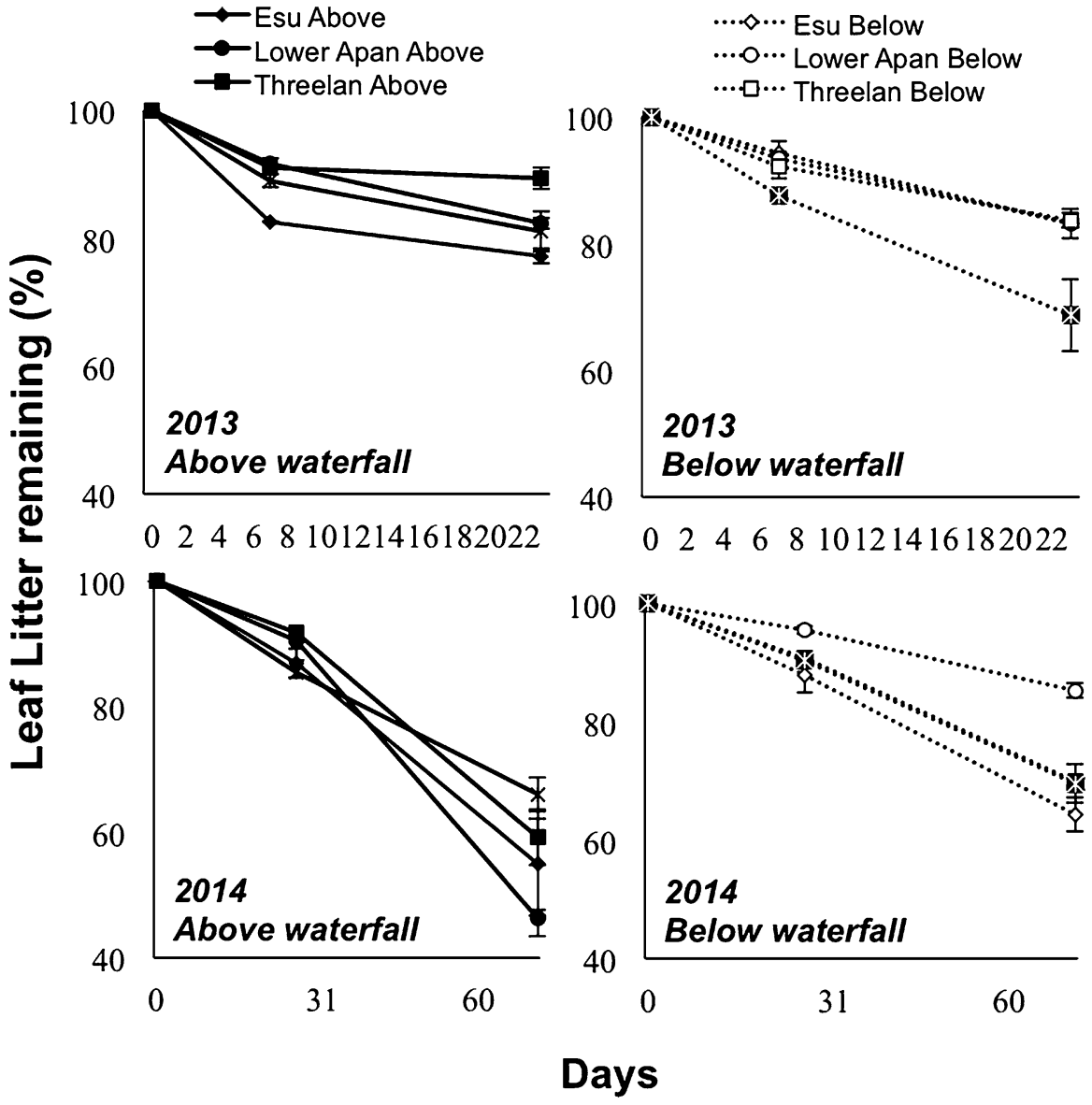

Biodiversity in above- and below-waterfall pools

As expected, the highest densities of fish were found in below-waterfall pools. We found waterfalls $(>6 \mathrm{~m}$ in height) acted as a barrier to fish at Esu, Threelan and Baki, likely creating a refuge for shrimp in the pools above waterfalls (Covich et al., 2009; Hein \& Crowl, 2010). Choy (1996) studied the distribution ecology of fish in the Ulu Temburong National Park and reported similar findings, with no Cyprinidae taxa recorded above any waterfall greater than $5 \mathrm{~m}$ in height. Gastromyzon fish were an exception; these herbivorous fish have a ventral sucker along their bodies and are therefore able to ascend vertical bedrock (Tan, 2006). However, despite this trait, surprisingly few Gastromyzon were observed in pools above waterfalls. This may be the result of the sampling design, as many Gastromyzon species inhabit faster flowing biotopes (Sheldon, 2011), which were not sampled in our study.
Macrobrachium, which were collected in Lower Apan, Esu and Threelan, are important members of aquatic communities. However, their impact on benthic environments has been mainly studied in Neotropical streams, with only a few studies conducted in Asia (e.g. Mantel et al., 2004). In the Neotropics, Macrobrachium have been found to exhibit aggressive behaviour, which can cause other shrimp to take shelter (Crowl \& Covich, 1994; March et al., 2001). This behaviour may explain the absence of other shrimp taxa sampled in our study sites. There were no significant differences in shrimp biomass and density among the streams. Among all pools above the waterfalls, there were significantly higher shrimp densities (Fig. 2). These results concur with similar findings in Puerto Rico, where shrimp occur in high abundances in above-waterfall pools (Pringle et al., 1993; March et al., 2002; Covich et al., 2009).

However, the high abundance of shrimp in abovewaterfall pools did not appear to have a significant 
Table 3 Periphyton growth rates (per day) on the rocks in pools above and below waterfalls at the four streams in 2013 (23-day exposures) and 2014 (72-day exposures)

\begin{tabular}{lll}
\hline & \multicolumn{2}{l}{ Periphyton growth rate $\left(\mathrm{g} \mathrm{m}^{-2}\right.$ days $\left.^{-1}\right)$} \\
\cline { 2 - 3 } & 2013 & 2014 \\
\hline Lower Apan, above & $0.12 \pm 0.01$ & $0.05 \pm 0.01$ \\
Lower Apan, below & $0.23 \pm 0.02$ & $0.05 \pm 0.02$ \\
Baki, above & $0.10 \pm 0.02$ & $0.06 \pm 0.003$ \\
Baki, below & $0.12 \pm 0.01$ & $0.12 \pm 0.01$ \\
Esu, above & $0.22 \pm 0.01$ & $0.06 \pm 0.001$ \\
Esu, below & $0.17 \pm 0.04$ & $0.21 \pm 0.01$ \\
Threelan, above & $0.19 \pm 0.01$ & $0.04 *$ \\
Threelan, below & $0.26 \pm 0.01$ & $0.13 \pm 0.02$
\end{tabular}

Growth rates were higher below the waterfalls in 2014 $(P \leq 0.01)$ but not in $2013(P=0.3)$. In 2014, there was also a difference in growth rates among streams $(P=0.02)$. * Only one experimental rock in the pool above the waterfall on Sungai Threelan due to the rocks being scoured out during flood events impact on macroinvertebrate communities, with the NMDS and ANOSIM procedures finding no difference in community patterns between macroinvertebrates in pools above and below the waterfalls. In the headwater streams of Puerto Rico, Ramirez \& Hernandez-Cruz (2004) conducted a shrimp exclusion experiment, which revealed Macrobrachium had mixed impacts on aquatic insects (i.e. the effects of shrimp were negligible in some streams). In another study in Puerto Rico, March et al. (2001) found that the impact of shrimp exclusion on insect biomass varied and was dependent on the genus of shrimp. In the highaltitude pools, exclusion of shrimp, which included $A$ tya spp. and Xiphocaris elongata (Guérin-Méneville, 1855), resulted in significantly lower insect biomass. In contrast, exclusion of Macrobrachium spp. in the low altitude pools promoted higher insect biomass. In our study, the low numbers of Macrobrachium in belowwaterfall pools had no apparent effect on

Table 4 Survey summary showing significant differences in animal communities and ecosystem functions among the study streams and between the above- and below-waterfall pools. Text in italic highlight significant differences

\begin{tabular}{|c|c|c|c|}
\hline Parameter & $\begin{array}{l}\text { All streams } \\
P \text { value }\end{array}$ & $\begin{array}{l}\text { Above and below } \\
\text { waterfall } P \text { value }\end{array}$ & Notes \\
\hline Fish density & 0.48 & 0.04 & $\begin{array}{l}\text { Higher fish density in below-waterfall pools. Gastromyzon } \\
\text { present above waterfalls at Esu (1) and Cyprinidae at Lower } \\
\text { Apan (3) }\end{array}$ \\
\hline Shrimp density & 0.18 & $<0.01$ & $\begin{array}{l}\text { Higher shrimp density in above-waterfall pools. Only } \\
\text { Macrobrachium present }\end{array}$ \\
\hline Macroinvertebrate density & 0.01 & 0.89 & Lower Apan exhibited the lowest density \\
\hline $\begin{array}{l}\text { Leaf litter 2013- } \\
7 \text { days }\end{array}$ & 0.15 & 0.1 & Faster decay rates in pools below waterfalls over 23 days \\
\hline $\begin{array}{l}\text { Leaf litter } 2013- \\
23 \text { days }\end{array}$ & $<0.01$ & $<0.01$ & \\
\hline $\begin{array}{l}\text { Leaf litter } 2014- \\
26 \text { days }\end{array}$ & $<0.01$ & $<0.01$ & Faster decay rates in pools above waterfalls over 26 days \\
\hline $\begin{array}{l}\text { Leaf litter 2014- } \\
\quad 71 \text { days }\end{array}$ & $<0.01$ & 0.07 & \\
\hline $\begin{array}{l}\text { Periphyton } \\
\text { (ambient) } 2013\end{array}$ & 0.12 & $<0.01$ & More periphyton below waterfalls \\
\hline $\begin{array}{l}\text { Periphyton } \\
\text { (ambient) } 2014\end{array}$ & 0.5 & 0.05 & \\
\hline $\begin{array}{l}\text { Periphyton growth } \\
2013\end{array}$ & 0.36 & 0.30 & Esu had the fastest periphyton growth below waterfalls \\
\hline $\begin{array}{l}\text { Periphyton growth } \\
2014\end{array}$ & $<0.01$ & $<0.01$ & \\
\hline
\end{tabular}


macroinvertebrate biomass, while in Costa Rica, fish and shrimp significantly reduced aquatic insects with combined effects greater than the summed effect of both groups individually (Pringle \& Hamazaki, 1998). These studies conducted in the Neotropics suggest that freshwater shrimp have an important role in structuring benthic community composition, but their effects vary and may depend on the presence or absence of other biota (March et al., 2002). In Hong Kong, Mantel et al. (2004) found no effect of the removal of Macrobrachium on aquatic insects; however, the authors were unable to determine the reason there was no effect. One explanation is that the macroinvertebrates consistently evaded fish and shrimp predators; this has been shown in studies that artificially doubled the natural densities of fish and failed to observe a decrease in some invertebrate taxa (Gilliam et al., 1989; Dudgeon, 1991). Our study also did not reveal a consistent pattern in macroinvertebrate diversity of above- and below-waterfall pools, suggesting that communities of shrimp and fish do not influence these biotic patterns; however, it is possible that fish and shrimp predators are substitutable and thus functionally redundant (sensu Ho \& Dudgeon, 2016).

In Northern Australia, Garcia et al. (2015) found that top-down effects on macroinvertebrates were context dependent with respect to factors such as benthic habitat, stream velocity and community structure, each of which influenced invertebrate diversity. Ulu Temburong has frequent flood events; for example, after a storm, it is not uncommon for the level of Belalong to rise by $1 \mathrm{~m}$ in a 30-min period (Cranbrook, 1993). These 'flashy flows' scour out habitats, physically removing taxa, and therefore may be more important in structuring macroinvertebrates than the presence of shrimp or fish (Bond \& Downes, 2000). The hypothesis that predation and competition are less important in highly disturbed streams and rivers has been suggested for systems in other parts of the world (Bishop, 1973; Peckarsky et al., 1990; Yang \& Dudgeon, 2010). Flash floods can create relatively unpredictable systems (Boulton et al., 2008) characterized by a continuum of conditions that may ultimately result in two distinct environments occurring at various times within a given portion of a stream. For example, during low flows, tropical streams are complex systems exhibiting a mix of flow biotopes (i.e. pools, riffles and cascades) and functional habitats (i.e. wood debris, leaf litter, cobbles and gravel; sensu Harper et al., 1995, Harvey et al., 2008); however, during a flood event, these streams become homogeneous as water rises to form a uniform flood biotope.

\section{Ecosystem functions}

It was assumed that differences in fish and shrimp densities would affect macroinvertebrate patterns along with leaf litter decomposition rates, ambient periphyton levels and periphyton growth rates. Specifically, past studies in the tropics have suggested that leaf litter decomposition can be increased by higher shrimp densities (March et al., 2001; Wright \& Covich, 2005), and herbivorous fish can increase periphyton levels (Pringle \& Hamazaki, 1997). We found ambient periphyton standing stocks and associated growth rates to be linked with higher fish densities, while leaf litter decomposition rates were unaffected by varying fish or shrimp densities.

The observed leaf litter decomposition rates were in the range of those from other tropical studies reported by Wantzen et al. (2008) with processing rates ranging from 0.001 days $^{-1}$ (Mathooko, 1998; Rueda-Delgado et al., 2006) to 0.789 days $^{-1}$ (Mathooko \& Kariuki, 2000). However, the lack of a correlation between fish, shrimp and macroinvertebrate occurrence parameters and breakdown rates suggests that leaf litter loss in our study sites was caused by other factors. Microbial processing has been suggested to be more important in the tropics compared to temperate regions (Irons et al., 1994). However, the importance of microbes to the decomposition of leaf litter is poorly understood, especially in the tropics (Boyero et al., 2011a, b), and thus, more research is required to understand the role of bacteria and fungi in breakdown rates. Mechanical abrasion from frequent floods in catchments can affect leaf litter breakdown, as has been demonstrated in other tropical studies (Pearson et al., 1989). Fast flows, which occur frequently in streams within Ulu Temburong, have been reported to cause physical abrasion of leaf litter, breaking debris down into smaller pieces and therefore influencing decomposition rates (Wantzen et al., 2008).

We found no significant differences in leaf litter decay between above- and below-waterfall pools. Many streams that flow through dipterocarp forests, such as our study sites, have very high tree diversity and leaves that are high in lignin and low in protein (Yule et al., 2009); such leaves possess an unappealing 
combination of traits for shredders. Landeiro et al. (2008) excluded fish and shrimp (mainly Macrobrachium) from leaf litter bags and found greater leaf litter breakdown in the control relative to the exclusion area. This could be linked with higher insect shredder abundances; however, there was no difference in shredder abundance between treatments, and the results were inconclusive. In spite of more recent research suggesting insect shredders do exist in tropical streams (Boyero et al., 2011a, b), our regression analysis showed no correlation between leaf litter breakdown rates with macroinvertebrate diversity. In our study, some leaf litter bags lacked any macroinvertebrates, for example, those in Lower Apan (e.g. the 2013, 23-day exposure bags in the below-waterfall pools; Table 3), suggesting that leaf litter is an unappealing food source for local macroinvertebrates.

Periphyton growth rates appear to be low compared to ambient periphyton levels, which is unsurprising because of the abundant herbivorous grazers and frequent scouring flows. However, some tropical fish have been found to be vitally important in increasing periphyton growth rates (Pringle \& Hamazaki, 1997; Moulton et al., 2010), which may explain high levels of ambient periphyton in below-waterfall pools and low periphyton growth rates in the above-waterfall pool of Apan Threelan $\left(0.04 \mathrm{~g} \mathrm{~m}^{-2}\right.$ days $\left.{ }^{-1}\right)$ where no fish were present. Overall abundance of ambient periphyton was correlated with the occurrence of fish. Pringle \& Hamazaki (1997) made similar findings; they observed fish influencing algal community composition, whereas shrimp had no significant effect. Studies have found herbivorous fish to be efficient in cleaning rock surfaces of deposited sediment after storm events, therefore helping increase periphyton levels (Pringle \& Hamazaki, 1997). This is important in tropical streams, such as our study streams, where fast flows are frequent and can both cause physical scouring and cover rocks in fine sediment (Wantzen et al., 2008). However, rates of accrual including grazing and scouring losses of periphyton among our study streams are not known.

Although many of the fish sampled in our study streams were not herbivorous, the literature contains studies in which even predacious fish have been shown to create trophic cascades. Moulton et al. (2010) found that predacious fish inhibit shrimp and baetid mayflies from grazing in two Neotropical streams, thus increasing both abundance and quality of periphyton in pools containing fish. However, other experiments have found that top-down effects of fish on algae have less impact relative to bottom-up effects such as increases in nutrient levels (Garcia et al., 2015; Ho \& Dudgeon, 2016). Interestingly, Ho \& Dudgeon (2016) found no impact of high numbers of fish and shrimp on algal biomass or periphyton accumulation in three Hong Kong streams. This was suggested to be caused by the removal of macroconsumers, which may have reduced nutrient levels and therefore contributed to the apparently weak top-down effects on fish and shrimp (Ho \& Dudgeon, 2016). Other factors, such as variation in sunlight across sites, may also affect periphyton levels; this requires further investigation across our study sites. However, as our experiments were conducted in pools directly above and below individual waterfalls, the pairs of sites experienced similar light levels.

\section{Conclusion}

As hypothesized, this study clearly illustrates that waterfalls affect habitat patterns of fish and shrimp, with waterfalls (generally $>5 \mathrm{~m}$ in height) acting as a barrier to the upstream dispersal of fish. This natural habitat fragmentation influenced algal biomass, but not litter breakdown. Our results show that even in a highly disturbed system, biotic interactions are still important. Further studies must be conducted to understand the effects of other factors, such as frequent scouring flows, which can have greater impacts than biotic factors. These findings suggest that streams divided into naturally discrete units by waterfalls have considerable ecological and conservation significance. Recent land-use changes caused by the widespread growth of the palm oil industry in Southeast Asia have increased the urgency of identifying and studying the remaining pristine rivers and streams. Understanding how natural discontinuities, such as waterfalls, can affect habitat patterns and ecosystem functions is vitally important to the successful management and conservation of these systems.

Acknowledgments We are grateful to the University of Brunei Darussalam (UBD) and The International Consortium of Universities for the Study of Biodiversity and the Environment (iCUBE). We extend a special thanks to the field boat people at Kuala Belalong Field Study Centre and Firdaus Ismail (undergraduate at UBD), our extremely 
helpful field assistant. This work was funded by a Natural Environment Research Council PhD studentship. Special thanks are also extended to Roy Whiles, Paul Clark, David Reid, Stephen Butler, Albert Orr, Manfred Jäch, Rüdiger Wagner, Virginija Podeniene, Marija Ivković, Herbert Zettel, Ignac Sivec, Ben Price, Michel Sartori and Jean Luc Gattolliat for their time in assisting with taxa identification. We thank Prof. NaselliFlores, Dr. Checo Colón-Gaud and the two anonymous reviewers for their insightful comments and help to improve this text.

Open Access This article is distributed under the terms of the Creative Commons Attribution 4.0 International License (http:// creativecommons.org/licenses/by/4.0/), which permits unrestricted use, distribution, and reproduction in any medium, provided you give appropriate credit to the original author(s) and the source, provide a link to the Creative Commons license, and indicate if changes were made.

\section{References}

Baker, K., M. A. Chadwick., R. A. Wahab \& R. Kahar, in press. Fluvial biotopes influence macroinvertebrate biodiversity in Southeast Asian tropical streams. Ecosphere.

Bass, D., 2007. Freshwater macroinvertebrates and their habitats in Dominica. Living World, Journal of the Trinidad and Tobago Naturalists Club 2007: 21-30.

Benke, A. C., A. D. Huryn, L. A. Smock \& J. B. Wallace, 1999. Length-mass relationships for freshwater macroinvertebrates in North America with particular reference to the Southeastern United States. Journal of North American Benthological Society 18: 308-343.

Benstead, J. P., 1996. Macroinvertebrates and the processing of leaf litter in a tropical stream. Biotropica 28: 367-375.

Bishop, J. E., 1973. Limnology of a Small Malayan River, Sungai Gombak. Dr. W. Junk Publishers, The Hague.

Bond, N. R. \& B. J. Downes, 2000. Flow-related disturbance in streams: an experimental test of the role of rock movement in reducing macroinvertebrate population densities. Marine and Freshwater Research 51: 333-337.

Boyero, L., R. G. Pearson, M. O. Gessner, L. A. Barmuta, V. Ferreira, M. A. S. Graça, D. Dudgeon, A. J. Boulton, M. Callisto, E. Chauvet, et al., 2011a. A global experiment suggests climate warming will not accelerate litter decomposition in streams but might reduce carbon sequestration. Ecology Letters 14: 289-294.

Boyero, L., R. G. Pearson, D. Dudgeon, M. A. S. Graça, M. O. Gessner, R. Albariño, V. Ferreira, C. M. Yule, A. J. Boulton, M. Arunachalam, M. Callisto, E. Chauvet, A. Ramírez, J. Chará, M. S. Moretti, J. F. J. Gonçalves, J. E. Helson, A. Chará-Serna, A. C. Encalada, J. N. Davies, S. Lamothe, A. Cornejo, A. O. Y. Li, L. M. Buria, V. D. Villanueva, M. C. Zúñiga \& C. M. Pringle, 2011b. Global distribution of a key trophic guild contrasts with common latitudinal diversity patterns. Ecology 92: 1839-1848.

Borcard, D., F. Gillet \& P. Legendre, 2012. Numerical Ecology with R. Springer, New York.
Boulton, A. J., L. Boyero, A. P. Covich, M. Dobson, S. Lake \& R. Pearson, 2008. Are tropical streams ecologically different from temperate streams? In Dudgeon, D. (ed.), Tropical Stream Ecology. Elsevier, London: 257-284.

Cheshire, K., L. Boyero \& R. G. Pearson, 2005. Food webs in tropical Australian streams: shredders are not scarce. Freshwater Biology 50: 748-769.

Choy, S. C. \& P. Chin, 1994. Fresh-water fishes from the headwaters of the Belalong-Temburong River System, Brunei-Darussalam, Borneo. Raffles Bulletin of Zoology 42: 757-774.

Choy, S. C., 1996. Distributional ecology of freshwater fishes in tropical rainforest streams of Borneo. In Edwards, D. S., Booth, W. E. \& Choy, S. C. (eds), Tropical Rainforest Research-Current Issues: Proceedings of the Conference held in Bandar Seri Begawan, April 1993. Springer, Dordrecht: 377-386

Clarke, K. R., 1993. Non-parametric multivariate analyses of changes in community structure. Austral Ecology 18:117-143.

Clayton, P. D. \& R. G. Pearson, 2016. Harsh habitats? Waterfalls and their faunal dynamics in tropical Australia. Hydrobiologia 775: 123-137.

Coughlan, J. F., R. G. Pearson \& L. Boyero, 2010. Crayfish process leaf litter in tropical streams even when shredding insects are common. Marine and Freshwater Research 61: 541-548.

Covich, A. P., T. A. Crowl, C. L. Hein, M. J. Townsend \& W. H. McDowell, 2009. Predator-prey interactions in river networks: comparing shrimp spatial refugia in two drainage basins. Freshwater Biology 54: 450-465.

Cranbrook, E. \& D. S. Edwards, 1994. Belalong, a Tropical Rainforest. Sun Tree Publishing Ltd, Singapore.

Cranbrook, E. O., 1993. Research and management of the Batu Apoi Forest Reserve, Temburong, Brunei: The Universiti Brunei Darussalam/Royal Geographical Society Rainforest Project 1991/92. Global Ecology and Biogeography Letters 3: 267-276.

Creed, R. P., 2006. Predator transitions in stream communities: a model and evidence from field studies. Journal of the North American Benthological Society 25: 533-544.

Crowl, T. A. \& A. P. Covich, 1994. Responses of a freshwater shrimp to chemical and tactile stimuli from a large decapod predator. Journal of the North American Benthological Society 13: 291-298.

Crowl, T. A., W. H. McDowell, A. P. Covich \& S. L. Johnson, 2001. Freshwater shrimp effects on detrital processing and nutrients in a tropical headwater stream. Ecology 82: 775-783.

Dudgeon, D., 1991. An experimental study of the effects of predatory fish on macroinvertebrates in a Hong Kong stream. Freshwater Biology 25: 321-330.

Dudgeon, D., 1999. Tropical Asian Streams: Zoobenthos, Ecology and Conservation. University Press, Hong Kong.

Dykes, A. P., 1994. Landfrom processes. In Cranbrook, E. O. \& D. Edwards (eds), Belalong: A Tropical Rainforest. Sun Tree Publishing Ltd, Singapore: 31-47.

Dykes, A. P., 1996. Analysis of factors contributing to the stability of steep hillslopes in the tropical rainforest of Temburong, Brunei Darussalam. In Edwards, D. S., Booth, W. E. \& Choy, S. C. (eds), Tropical Rainforest ResearchCurrent Issues: Proceedings of the Conference held in 
Bandar Seri Begawan, April 1993. Springer, Dordrecht: 377-386

El-Sabaawi, R. W., M. C. Marshall, R. D. Bassar, A. LópezSepulcre, E. P. Palkovacs \& C. Dalton, 2015. Assessing the effects of guppy life history evolution on nutrient recycling: from experiments to the field. Freshwater Biology 60: 590-601.

Everaert, G., J. De Neve, P. Boets, L. Dominguez-Granda, S. T. Mereta, A. Ambelu, T. H. Hoang, P. L. Goethals \& O. Thas, 2014. Comparison of the abiotic preferences of macroinvertebrates in tropical river basins. PloS One 9: e108898.

Feminella, J. W. \& C. P. Hawkins, 1995. Interactions between stream herbivores and periphyton: a quantitative analysis of past experiments. Journal of the North American Benthological Society 14: 465-509.

Flecker, A. S. \& B. W. Taylor, 2004. Tropical fishes as biological bulldozers: density effects on resource heterogeneity and species diversity. Ecology 85: 2267-2278.

Flecker, A. S., 1992. Fish trophic guilds and the structure of a tropical stream: weak direct vs. strong indirect effects. Ecology 73: 927-940.

Garcia, E. A., S. A. Townsend \& M. M. Douglas, 2015. Context dependency of top-down and bottom-up effects in a Northern Australian tropical river. Freshwater Science 34: 679-690.

Giller, P. S. \& B. Malmqvist, 1998. The Biology of Streams and Rivers. Oxford University Press, USA.

Gilliam, J. F., D. F. Fraser \& A. M. Sabat, 1989. Strong effects of foraging minnows on a stream benthic invertebrate community. Ecology 70: 445-452.

Gordon, N. D., B. L. Finlayson \& T. A. McMahon, 2004. Stream Hydrology: An Introduction for Ecologists. Wiley, New York.

Greathouse, E. A. \& C. M. Pringle, 2006. Does the river continuum concept apply on a tropical island? Longitudinal variation in a Puerto Rican stream. Canadian Journal of Fisheries and Aquatic Sciences 63: 134-152.

Harper, D., C. Smith, P. Barham \& R. Howell, 1995. The ecological basis for the management of the natural river environment. In Harper, D. M. \& A. J. D. Ferguson (eds), The Ecological Basis for River Management. Wiley, Chichester: 219-238.

Harvey, G. L., N. J. Clifford \& A. M. Gurnell, 2008. Towards an ecologically meaningful classification of the flow biotope for river inventory, rehabilitation, design and appraisal purposes. Journal of environmental management 88: 638-650.

Hein, C. L. \& T. A. Crowl, 2010. Running the predator gauntlet: do freshwater shrimp (Atya lanipes) migrate above waterfalls to avoid fish predation? Journal of the North American Benthological Society 29: 431-443.

Ho, B. S. K. \& D. Dudgeon, 2016. Are high densities of fishes and shrimp associated with top-down control of tropical benthic communities? A test in three Hong Kong streams. Freshwater Biology 61: 57-68.

Irons, J. G., M. W. Oswood, R. J. Stout \& C. M. Pringle, 1994. Latitudinal patterns in leaf litter breakdown: is temperature really important? Freshwater Biology 32: 401-411.

Jinggut, T., 2015. Leaf Litter Breakdown in Streams of East Malaysia, Borneo: A Study of Biodiversity and Ecosystem
Functioning. Monash University Sunway Campus, Subang Jaya.

Karssing, R. J., N. A. Rivers-Moore \& K. Slater, 2012. Influence of waterfalls on patterns of association between trout and Natal cascade frog Hadromophryne natalensis tadpoles in two headwater streams in the uKhahlamba Drakensberg Park World Heritage Site, South Africa. African Journal of Aquatic Science 37: 107-112.

Kottelat, M., 2013. The fishes of the inland waters of Southeast Asia: a catalogue and core bibliography of the fishes known to occur in freshwaters, mangroves and estuaries. Raffles Bulletin of Zoology 27: 1-663.

Landeiro, V. L., N. Hamada \& A. S. Melo, 2008. Responses of aquatic invertebrate assemblages and leaf breakdown to macroconsumer exclusion in Amazonian "terra firme" streams. Fundamental and Applied Limnology 172: 49-58.

Mantel, S. K., M. Salas \& D. Dudgeon, 2004. Foodweb structure in a tropical Asian forest stream. Journal of the North American Benthological Society 23: 728-755.

March, J. G., J. P. Benstead, C. M. Pringle \& M. W. Ruebel, 2001. Linking shrimp assemblages with rates of detrital processing along an elevational gradient in a tropical stream. Canadian Journal of Fisheries and Aquatic Sciences 58: 470-478.

March, J. G., C. M. Pringle, M. J. Townsend \& A. I. Wilson, 2002. Effects of freshwater shrimp assemblages on benthic communities along an altitudinal gradient of a tropical island stream. Freshwater Biology 47: 377-390.

Masese, F. O., N. Kitaka, J. Kipkemboi, G. M. Gettel, K. Irvine \& M. E. McClain, 2014. Macroinvertebrate functional feeding groups in Kenyan highland streams: evidence for a diverse shredder guild. Freshwater Science 33: 435-450.

Mathooko, J. M. \& S. T. Kariuki, 2000. Disturbances and species distribution of the riparian vegetation of a Rift Valley stream. African Journal of Ecology 38: 123-129.

Mathooko, J. M., 1998. The effect of continuous physical disturbance on mayflies of a tropical stream: an experimental approach. Hydrobiologia 362: 209-216.

McConnell, R. \& R. H. Lowe-McConnell, 1987. Ecological Studies in Tropical Fish Communities. Cambridge University Press, Cambridge.

McNeely, C., J. C. Finlay \& M. E. Power, 2007. Grazer traits, competition, and carbon sources to a headwater-stream food web. Ecology 88: 391-401.

Moulton, T. P., M. L. Souza, R. M. L. Silveira, F. A. M. Krsulović, M. P. Silveira, J. C. F. de Assis \& C. N. Francischetti, 2010. Patterns of periphyton are determined by cascading trophic relationships in two neotropical streams. Marine and Freshwater Research 61: 57-64.

Moulton, T. P., C. Lourenço-Amorim, C. Y. Sasada-Sato, V. Neres-Lima \& E. Zandonà, 2015. Dynamics of algal production and ephemeropteran grazing of periphyton in a tropical stream. International Review of Hydrobiology 100: 61-68.

Newson, M. \& C. Newson, 2000. Geomorphology, ecology and river channel habitat: mesoscale approaches to basin-scale challenges. Progress in Physical Geography 24: 195-217.

Pearson, R. G., R. K. Tobin, R. E. W. Smith \& L. J. Benson, 1989. Standing crop and processing of rainforest litter in a tropical Australian stream. Archiv für Hydrobiologie 115: 481-498. 
Peckarsky, B. L., S. C. Horn \& B. Statzner, 1990. Stonefly predation along a hydraulic gradient: a field test of the harsh-benign hypothesis. Freshwater Biology 24: 181-191.

Power, M. E., 1984. The importance of sediment in the grazing ecology and size class interactions of an armored catfish, Ancistrus spinosus. Environmental Biology of Fishes 10: 173-181.

Pringle, C. M. \& T. Hamazaki, 1997. Effects of fishes on algal response to storms in atropical stream. Ecology 78: 2432-2442.

Pringle, C. M. \& T. Hamazaki, 1998. The role of omnivory in a neotropical stream: separating diurnal and nocturnal effects. Ecology 79: 269-280.

Pringle, C. M., G. A. Blake, A. P. Covich, K. M. Buzby \& A. Finley, 1993. Effects of omnivorous shrimp in a montane tropical stream: sediment removal, disturbance of sessile invertebrates and enhancement of understory algal biomass. Oecologia 93: 1-11.

Rackemann, S. L., B. J. Robson \& T. G. Matthews, 2013. Conservation value of waterfalls as habitat for lotic insects of western Victoria, Australia. Aquatic Conservation: Marine and Freshwater Ecosystems 23: 171-178.

Ramirez, A. \& L. R. Hernandez-Cruz, 2004. Aquatic insect assemblages in shrimp-dominated tropical streams, Puerto Rico. Biotropica 36: 259-266.

Ramírez, A. \& C. M. Pringle, 1998. Structure and production of a benthic insect assemblage in a Neotropical stream. Journal of the North American Benthological Society 17: 443-463.

R Core Team., 2013. R: A language and environment for statistical computing. R Foundation for Statistical Computing, Vienna, Austria.

Rosemond, A. D., C. M. Pringle \& A. Ramírez, 1998. Macroconsumer effects on insect detritivores and detritus processing in a tropical stream. Freshwater Biology 39: $515-523$.

Rueda-Delgado, G., K. M. Wantzen \& M. B. Tolosa, 2006. Leaf-litter decomposition in an Amazonian floodplain stream: effects of seasonal hydrological changes. Journal of the North American Benthological Society 25: 233-249.

Sabo, J. L., J. L. Bastow \& M. E. Power, 2002. Length-mass relationships for adult aquatic and terrestrial invertebrates in a California watershed. Journal of the North American Benthological Society 21: 336-343.
Sangpradub, N. \& B. Boonsoong, 2007. Identification of Freshwater Invertebrates of the Mekong River and Its Tributaries. Technical Publications, Mekong River Commission, Vientiane.

Sheldon, A. L., 2011. Comparative habitat use by grazing fishes in a Bornean stream. Environmental Biology of Fishes 92: 381-390.

Steinman, A. D., 1996. Effects of grazers on freshwater benthic algae. In Stevenson, R. J., M. L. Bothwell \& R. L. Lowe (eds), Algal Ecology: Freshwater Benthic Ecosystems. Academic Press, San Diego: 341-374.

Tan, H. H., 2006. The Borneo suckers. Revision of the torrent loaches of Borneo (Balitoridae: Gastromyzon, Neogastromyzon). Natural History Publications (Borneo), Kota Kinabalu.

Thomas, R., I. Vaughan \& J. Lello, 2013. Data Analysis with R Statistical Software: A Guidebook for Scientists. Eco-explore, Cardiff.

Wantzen, K. M., C. M. Yule, J. M. Mathooko \& C. M. Pringle, 2008. Organic matter processing in tropical streams. In Dudgeon, D. (ed.), Tropical Stream Ecology. Academic Press, London.

Waters, T. F., 1977. Secondary production in inland waters. Advances in Ecological Research 10: 91-164.

Wellnitz, T. \& N. Leroy Poff, 2006. Herbivory, current velocity and algal regrowth: how does periphyton grow when the grazers have gone? Freshwater Biology 51: 2114-2123.

Wootton, J. T. \& M. P. Oemke, 1992. Latitudinal differences in fish community trophic structure, and the role of fish herbivory in a Costa Rican stream. Environmental Biology of Fishes 35: 311-319.

Wright, M. S. \& A. P. Covich, 2005. The effect of macroinvertebrate exclusion on leaf breakdown rates in a tropical headwater stream. Biotropica 37: 403-408.

Yang, G. Y. \& D. Dudgeon, 2010. Response of grazing impacts of an algivorous fish (Pseudogastromyzon myersi: Balitoridae) to seasonal disturbance in Hong Kong streams. Freshwater Biology 55: 411-423.

Yule, C. M. \& H. S. Yong, 2004. Freshwater Invertebrates of the Malaysian Region. Academy of Sciences Malaysia Kuala Lumpur, Kuala Lumpur.

Yule, C. M., M. Y. Leong, K. C. Liew, L. Ratnarajah, K. Schmidt, H. M. Wong, R. G. Pearson \& L. Boyero, 2009. Shredders in Malaysia: abundance and richness are higher in cool upland tropical streams. Journal of the North American Benthological Society 28: 404-415. 